KERUSSO, VOLUME 3 NUMBER 1 MARET 2018

\title{
MENGANTISIPASI PERUBAHAN RADIKAL DALAM PERJALANAN SEORANG PEMIMPIN KRISTEN
}

\author{
Tantra Lingga Weinardy ${ }^{1)}$, Andre Yulius ${ }^{2)}$, Saibun Panjaitan ${ }^{3)}$, Antoni Bastian ${ }^{4)}$, Daniel Gunarso ${ }^{5}$ \\ ${ }^{1)}$ Sekolah Tinggi Teologi Abdi Gusti, Nganjuk, Indonesia \\ E-mail: tantra@sttabdigusti.ac.id \\ ${ }^{2}$ Sekolah Tinggi Teologi Abdi Gusti, Nganjuk, Indonesia \\ E-mail: andre@sttabdigusti.ac.id \\ ${ }^{3}$ Sekolah Tinggi Teologi Abdi Gusti, Nganjuk, Indonesia \\ E-mail: jefry@sttabdigusti.ac.id \\ ${ }^{4)}$ Sekolah Tinggi Teologi Abdi Gusti, Nganjuk, Indonesia \\ E-mail:antoni@sttabdigusti.ac.id \\ ${ }^{5)}$ Sekolah Tinggi Teologi Abdi Gusti, Nganjuk, Indonesia \\ E-mail:daniel@sttabdigusti.ac.id
}

\begin{abstract}
Changes in our Life might not always be detectable, even sometimes the scale of changes can be as radical as we can imagine. This radical changes also happen in every Leader's Journey of Life whether he or she likes it or not. However, Leaders should learn to accept it or further than that Leaders should anticipate the changes with open minded and ready to adjust his/her leadership style so that he/she can brings the whole team to achieve the goal that have been set for their purpose. Moreover, Leaders must introspects a few points of indicators that can broaden up to his/her personal acceptance upon this radical changes and turn it to his/her advantage to leap and overcome the changes for the sake of his/her life, the organization and his/her fellowmen.
\end{abstract}

Keywords: Change, Leaders, Radical, Goal, Purpose, Anticipating

\section{I.PENDAHULUAN}

Kehidupan seorang Pemimpin tentunya tidak terlepas dari pengaruh - pengaruh yang ada di sekitarnya, bahkan seringkali pengaruh - pengaruh di sekitarnya memberikan dampak yang sangat luas kepada kehidupan Pemimpin itu sendiri baik terhadap kehidupan pribadi sang Pemimpin, kehidupan dari organisasi yang dipimpin dan juga tentunya kehidupan dari pengikut - pengikutnya.

Seorang Pakar Kepemimpinan bernama John C. Maxwell memberikan pandangannya yaitu Pertumbuhan
Kepemimpinan sesungguhnya merupakan perjalanan seumur hidup - dan bukan perjalanan yang singkat. Pertumbuhan Kepemimpinan itu tidak dapat kita peroleh dari sebuah konferensi, melainkan kita harus menyerahkan hidup kita untuk itu. [1]

Dari penjelasan di atas maka dapat kita lihat bahwa kalau kita berbicara mengenai seorang Pemimpin dapatlah dipastikan bahwa Pemimpin itu harus memberikan dirinya dalam perjalanan kepemimpinannya. Terlepas bahwa sang Pemimpin ini ada terus 
dalam satu organisasi atau karena satu dan lain hal membuat sang pemimpin ini harus berpindah tempat dan secara jelas apa yang disampaikan oleh Bapak John C. Maxwell di atas menyebutkan bahwa pemimpin ini tetaplah seorang pemimpin karena seperti ungkapan Warren G. Bennis "Kepemimpinan adalah kemampuan untuk membawa visi menjadi kenyataan.", memberikan gambaran bahwa Kepemimpinan yang efektif tahu bagaimana mengambil langkah-langkah untuk bertindak bagi dirinya dan organisasinya sehingga sebuah visi dapat diwujudkan.[2]

Berbicara mengenai perjalanan hidup pemimpin, maka kita semakin jelas melihat bahwa akan ada hal - hal baik besar maupun kecil yang akan mempengaruhi keberadaan pemimpin, dan itu berakibat kepada perubahan yang harus dihadapi oleh pemimpin. Perubahan itu sendiri ada yang bisa diketahui pergerakannya, namun perubahan juga ada yang sama sekali datang secara mendadak dan memberikan dampak atau pengaruh yang besar karena perubahan itu sendiri begitu masif dan radikal.

Untuk lebih jelasnya, Penulis bermaksud mengajak kita semua melihat Apa yang dialami oleh seorang Nehemia, ketika dia yang bertugas selaku Juru minum Raja Arthasasta, di Babel, mengikuti keadaan kota Yerusalem yang temboknya terbongkar dan pintu-pintu gerbangnya terbakar, berdoa kepada Tuhan untuk meminta keberhasilan ketika Nehemia ini mengajukan permohonan kepada Raja Arthasasta. Baru setelah 4 bulan, tepatnya di bulan Nisan, seperti yang tertulis dalam Kitab Nehemia 2:1, menyebutkan bahwa Nehemia ini 'tertangkap-basah' sedang tidak bersukacita dalam menjalankan tugasnya selaku juru minum raja.[3]

Dalam proses percakapan antara Nehemia dengan Raja Arthasasta yang ditemani oleh permaisuri, dapat kita ketahui bahwa kerinduan Nehemia ini untuk dapat melakukan perbaikan tembok dan pagar di Yerusalem, oleh kemurahan Tuhan, dikabulkan oleh Raja Arthasasta setelah Nehemia menyebutkan berapa lama dia dapat menyelesaikannya (dalam kenyataannya Tembok dan Pagar di kota Yerusalem ini selesai dalam waktu 52 hari).

\section{PERMASALAHAN}

Yang menjadi menarik dari hasil pembicaraan dengan Raja Arthasasta seperti yang penulis sampaikan di atas adalah bagaimana Raja Arthasasta ini memberikan ijin kepada Nehemia untuk melanjutkan kerinduan hatinya memugar Tembok dan Pintu Gerbang Kota Yerusalem. Tentunya, Ikut campur Tuhan dalam menggerakkan hati Raja Arthasasta, turut berperan besar sehingga semua ini menjadi nyata.

Dengan persetujuan Raja Arthasasta ini tentunya membuat perubahan besar dalam kehidupan Nehemia, baik secara karir sebagai juru minum raja, maupun kehidupannya yang selama ini tinggal dan hidup nyaman di Istana di Babel dan harus secara mendadak melakukan perjalanan kembali ke kota Yerusalem, dan tentunya akan memberikan dampak yang luar biasa.

Jika Nehemia tidak memiliki keteguhan dalam melangkah, meski doa Nehemia terjawab namun belum tentu Nehemia akan siap menghadapi perubahan yang drastis dengan meninggalkan semua fasilitas yang Nehemia terima di Istana Raja Arthasasta di Babel.

Penulis juga mencoba mengambil satu tokoh dalam Alkitab yang juga mengalami perubahan drastis atau radikal dalam kehidupannya mengiring Tuhan dan melaksanakan tugas yang harus diembannya yaitu Nabi Elia, nabi yang sangat terkenal karena memiliki pengalaman melakukan mujizat - mujizat yang termasuk fenomenal di jamannya. [4]

Dalam Kitab I Raja-Raja 17:1-6, terlihat jelas gambaran yang dipaparkan bagaimana kehidupan yang harus dilewati Nabi Elia, dari kehidupan yang menyenangkan di Kota Tisbe-Gilead, sebuah daerah yang kecil, bahkan kota Gilead digambarkan oleh Charles R. Swindoll adalah suatu tempat terpencil, tempat dimana orang-orangnya mungkin kuat-kuat, terbakar sinar matahari, berotot, bukan tempat berdiplomasi dan tergolong sebagai daerah yang tidak menyenangkan.[5]

Meski terlihat bukan kota atau daerah yang menarik, kota kelahiran selalu merupakan kota yang akan memberikan kenyamanan kepada warganya dan memberikan kehidupan serta akan menjadi tempat jujukan yang akan sulit untuk ditinggalkan. Namun, karena Elia harus menjalankan tugasnya sebagai Nabi atau penyambung lidah Allah, ketika Elia diminta untuk meninggalkan Tisbe-Gilead dan menetap di Sungai Kerit yang ada di sebelah timur Sungai Yordan, hal ini memberikan perubahan yang besar pula bagi kehidupan seorang Nabi Elia. 
Memang dalam alkitab tidak diceritakan bagaimana kehidupan keluarga Elia, apakah menikah, apakah memiliki anak, tidaklah digambarkan secara jelas dalam kitab I Raja-Raja 17 tersebut, namun secara akal sehat, penulis merasa pasti bahwa Nabi Elia ini tentu memiliki orang tua yang tinggal di Tisbe-Gilead, juga sanak family, sehingga perintah Tuhan kepada Nabi Elia untuk meninggalkan tempat asalnya dan pindah ke Sungai Kerit pastinya akan memberikan perubahan yang radikal dalam kehidupan Nabi Elia itu sendiri.

Dan Permasalahan akan semakin jelas kalau kita sebagai pemimpin (termasuk di dalamnya pejabat gereja, aktivis gereja dan juga gembala sebuah gereja) tidak siap dan bahkan cenderung menolak untuk menerima panggilan dan atau perintah yang kita yakini sebagai tugas khusus dari Tuhan sehingga kita jauh dari kenyataan sikap yang diambil oleh Seorang Nehemia dan Nabi Elia seperti yang Penulis sampaikan di atas.

Permasalahan sikap dan bagaimana langkah mengantisipasi perubahan yang radikal ini yang coba penulis tuangkan dalam artikel ini dengan mengambil gambaran situasi yang dihadapi oleh seorang Nehemia saja dan merujuknya kepada studi kepustakaan sebagai pendekatan yang penulis coba lakukan yaitu studi kepustakaan dengan mengumpulkan berbagai bahan dari buku, artikel dalam jurnal, hasil penelitian, serta data dan informasi lainnya yang diperlukan terkait dengan penelitian ini.

Penulis juga melakukan pendekatan metode penelitan secara kualitatif seperti yang disampaikan Menurut Moleong (2005:6), penelitian kualitatif adalah penelitian yang bermaksud untuk memahami fenomena tentang apa yang dialami oleh subjek penelitian misalnya perilaku, persepsi, motivasi, tindakan, dll secara holistic, dan dengan cara deskripsi dalam bentuk kata-kata dan bahasa, pada suatu konteks khusus yang alamiah dan dengan memanfaatkan berbagai metode alamiah.[6]

Untuk menjawab permasalahan di atas, Semuanya akan Penulis paparkan dalam pembahasan di bawah ini termasuk langkah-langkah yang disampaikan oleh para peneliti sebelumnya.

\section{KAJIAN TEORETIS}

Ada hal yang menarik dari seorang Spencer Johnson, M.D. saat penulis ini membuat buku "Who Moved My Cheese?"[7] karena buku ini adalah menggambarkan perumpamaan sederhana yang mengungkapkan kebenaran sejati tentang perubahan. Dengan cara yang sangat menyenangkan dan memberikan pencerahan, dikisahkan tentang empat tokoh yang hidup dalam sebuah "Labirin" yang mencari "Cheese" untuk mempertahankan hdiup dan membuat hidup mereka bahagia.

Dua di antaranya adalah tikus yang bernama "Sniff" dan "Scurry", dan dua lagi adalah "kurcaci" sebesar tikus yang bergerak dan bertindak persis seperti kita - manusia. Nama mereka adalah "Hem" dan "Haw".

"Cheese" melambangkan hal-hal yang kita inginkan dalam hidup - baik pekerjaan yang baik, hubungan yang harmonis, uang, kekayaan, kesehatan atau ketenangan bathin.

Dan "Labirin" adalah tempat di mana kita mencari apa yang kita inginkan - perusahaan di mana kita bekerja, atau keluarga atau masyarakat di sekitar kita.

Dikisahkan keempat tokoh tersebut menghadapi perubahan yang tidak terduga sebelumnya.Namun demikian satu di antaranya berhasil mengatasinya, dan menuliskan pelajaran yang diperolehnya dari pengalaman tersebut di dinding Labirin.

Spencer Johnson ingin membagikan kepada kita bahwa kadang kala kita bertindak seperti : Tokoh"Sniff" Yang mampu mencium adanya perubahan dengan cepat. Atau kadang kita menjadi tokoh "Scurry" yang segera bergegas mengambil tindakan, atau juga mengambil peran tokoh "Hem" Yang menolak serta mengingkari adanya perubahan karena takut perubahan akan mendatangkan sesuatu yang buruk atau bisa menjadi tokoh "Haw" yang harus mencoba beradaptasi jika kita melihat perubahan mendatangkan sesuatu yang lebih baik. Akan Tetapi apapun peran dan bagian yang kita pilih dan mainkan seperti yang disampaikan di atas, kita mempunyai ciri yang sama yaitu: KEBUTUHAN untuk MENEMUKAN JALAN dalam Labirin dan SUKSES MENGATASI perubahan yang kita hadapi.

Buku Ini akhirnya memberikan langkah - langkah yang harus kita pahami dan lakukan yaitu: 
(1) Bahwa Perubahan selalu terjadi

(2) Bahwa Perlunya Antisipasi Perubahan

(3) Bahwa Perhatikan Perubahan

(4) Bahwa Penting Sesuaikan diri dengan cepat

(5) Bahwa Harus BERUBAH

(6) Bahwa Perlu menikmati Perubahan

(7) Akhirnya Bersiaplah Berubah dengan Cepat dan Nikmatilah Lagi dan Lagi.

Lain Spencer Johnson lain pula yang diutarakan oleh Richard Templar, seorang penulis buku yang berjudul: "I Don't Want Any More Cheese" [8] yang menyampaikan pandangan yang menggelitik sebagai berikut:

Kadang kala, kita membutuhkan tendangan kosmis.Dipecat atau dicopot dari posisi yang Kita pegang bisa menjadi sebuah malapetaka.Bagaimana kita melihat hal tersebut?Dapatkah kit menganggapnya sebagai tiket untuk meraih kemerdekaan ataukah merupakan jalan menuju keputus-asaan? Itu semua terserah kita.Kita bisa merasa marah, merasa ditolak, ingin mengumpat, atau mengancam mereka dengan tuntutan hukum. Atau malah pergi diam-diam sambil bersiul.Itu Pilihan kita, tapi tidak usah bercerita kepada siapapun.

Pada dasarnya, menurut Richard Templar, pihak lain tersebut sedang memangkah jumlah "Keju" yang kita terima dan kita semestinya harus merasa berterima kasih. Hal itu pasti datang sebagai guncangan. Pasti kita merasa dicurangi, dikecewakan, dan marah, rasanya begitu menyakitkan, Apa salah saya? Kenapa saya gagal untuk meraih kesempatan dan bertahan di sana? Saya bekerja keras untuk kembali meraih puncak kejayaan.Sesungguhnya, begitu saya kembali menguasai keadaan, saya memandang sekeliling dan menyadari bahwa berada kembali ke puncak tidak begitu mengasyikkan seperti yang dulu saya pikir.Posisi itu telah kehilangan daya tariknya dan saya berusaha untuk melarikan diri secepat yang saya bisa.Dan ya, saya juga pernah mengalami semua hal yang harus dilalui - bagaimana dengan gaji bulanan?Apa yang akan dikatakan oleh keluarga saya? Ke mana sya akan pergi dan apa yang akan saya lakukan? Ya, Saya juga memiliki semua pertanyaan itu dan jawabannya entah bagaimana muncul dan berusaha saya temukan.
Meninggalkan pekerjaan dengan gaji yang bagus untuk mengikuti kata hati dapat menghasilkan efek samping yang mungkin belum anda pertimbangkan atau bayangkan.Karena :

(1) Orang lain di sekitar Anda akan mengira Anda Gagal

(2) Anda akan merasa gagal (atau melarikan diri dari kenyataan)

(3) Tak ada orang yang tertarik dengan impian Anda.

(4) Anda merasa kesulitan untuk berkata selamat tinggal

(5) Anda merasa tahun-tahun yang sudah Anda habiskan untuk membangun karier telah disiasiakan.

(6) Anda merindukan teman-teman dan sisi sosial dari pekerjaan Anda lebih dari yang anda duga sebelumnya.

Efek samping di atas berbeda dari efek normal yang dirasakan beberapa orang seperti merasa kesepian pada awalnya, merasa dikuliti, harus menjalani masa belajar yang sulit ketika berusaha menjalani impian Anda, dan lain sebagainya.

Dan Akhirnya, Richard Templar menyampaikan: Kalau kita sudah mulai bosan dengan "Keju" dan ingin melarikan diri dari perangkap, Kita harus mengikuti proses yang logis agar pelarian Kita membawa hasil. Ini adalah proses yang harus kita jalani:

- Miliki impian

Jangan biarkan orang lain memadamkan impian kita. Kita harus mempertahankan impian kita apapun yang terjadi karena selalu aka nada orang yang akan mentertawakan atau membenci kita bahkan mencoba membunuh kita karena mereka tidak memiliki impian seperti kita.

- Ketahui Apa yang Kita Inginkan Yang kita inginkan adalah keluar dan itu artinya sekarang. Mengetahui apa yang kita inginkan berarti meraih impian kita, berarti membayangkan diri kita dalam impian itu, berarti mengetahui apa yang kita tidak inginkan, dan berarti memahami apa yang 
membuat kita hebat juga mengetahui hal-hal apa yang cocok dengan kita

- Berbicaralah kepada Orang lain

Untuk meletakkan fondasi yang bisa membantu impian kita menjadi kenyataan.Berbicara kepada orang yang kita sayangi dan bukan dengan para pencemooh. Sebab dengan berbicara kepada orang yang kita sayangi, kita akan mendapatkan umpan balik, gagasan baru, dukungan, masukan, komentar, pendapat, pandangan, perbaikan, dan tanggapan.

- Buatlah rencana

Rencana lah yang mengubah impian menjadi kenyataan, karena rencana adalah peta kita menuju kenyataan, dengan rencana, kita akan menemukan jalan, mengikuti serangkaian langkah, memiliki panduan dan pada dasarnya kita bisa kembali dengan mudah ketika kita sudah mulai kehilangan arah. Sebab Rencana akan memberi kita tujuan dan kestabilan.

- Mulailah langkah pertama

Terserah apa yang akan kita lakukan selama kita memang melakukan sesuatu, sebab begitu kita membuat langkah pertama, hal - hal akan berubah karena kita telah melakukan perubahan.

Keluar dari perangkap juga mirip seperti itu, kalau kita melakukan sesuatu, maka dunia akan berputar dan tanpa kita sadari, kita telah membuka diri untuk perubahan, untuk "memaksa" alam semesta yang mempengaruhi perubahan.

- Katakan Selamat Tinggal.

Begitu kita membuat langkah pertama, maka kita siap untuk berkata selamat tinggal, dan itu berarti perpisahan dengan apapun yang ingin kita tinggalkan.

Di bagian Permasalahan di atas, penulis mencoba mengambil tokoh pembanding dari Alkitab yaitu Nabi Elia, untuk mempermudah bagi kita melihat bagaimana seharusnya Pemimpin sekelas Nehemia menghadapi perubahan yang radikal dalam pengiringannya kepada Tuhan Allah, yang sering dikenal dan disebut Elohim itu.
Digambarkan oleh Charles R. Swindoll dalam buku yang sudah penulis sampaikan di atas[9] menyebutkan bahwa Elia adalah seorang pria yang mempunyai misi, ia memproklamirkan dirinya sebagai hamba"Tuhan, Allah Israel", ketika semua yang di sekelilingnya merupakan bukti dari penyembahan Baal. Elia menawarkan sesuatu.Dia adalah seorang utusan yang berdiri teguh sebagai perantara, diurapi secara unik dan dipakai oleh Allah.Dia bepergian sendirian, membunyikan tanda peringatan, mencoba untuk membangunkan yang tidak peduli dan bahkan kepada musuh.

Charles R. Swindoll menyebutkan bahwa pencarian masih berlanjut.Tuhan kita masih mencari orangorang yang mau membuat perbedaan. Orang-orang Kristen yang tidak mau hanya menjadi cukup dan melalui kehidupan Elia mengajarkan kepada kita tentang apa yang Tuhan Inginkan, yaitu:

(a) Allah mencari orang-orang khusus pada masamasa sulit.

Tuhan mencari orang - orang yang memiliki tulang punggung yang kuat sehingga ia dapat berdiri sendiri. Seseorang yang memiliki kekuatan untuk dapat berkata: "Itu Salah!" Seseorang yang dapat berdiri berhadapan dengan penyembah berhala dan memproklamirkan, "Tuhan adalah Allah". Tetapi mereka yang menemukan kenyamanan di tahta Ahab tidak akan pernah membawa diri mereka untuk berdiri sebagai perantara bersama Allah.

(b) Metode Allah kadang kala mengejutkan Allah melakukan sesuatu yang tidak terbayangkan - Dia memilih seseorang seperti Elia.Jika saat ini Pelayanan kita mungkin hanya berkisar dua atau tiga orang, janganlah menganggapnya remeh. Metode dan cara Allah kadang mengejutkan. Dalam Faktanya, kadang kita merasa bahwa cara Allah tidak logis, cara tersebut tidak masuk dalam akal kita. SaudaraSaudara Daud mentertawakan idenya untuk bertarung melawan Goliath.Dan bagaimana dengan Yosua yang mengelilingi tembok Yerikho dan meniup terompet? Kita sedang membicarakan sesuatu yang tidak wajar. 
KERUSSO, VOLUME 3 NUMBER 1 MARET 2018

(c) Kita berdiri di hadapan Allah

Kerika kita berdiri sebagai perantara, artinya kita sedang berdiri di hadapan Allah. Ketika panggilan datang, apakah Tuhan akan menemukan kita siap dan rela untuk berdiri bagi-Nya? Akankah Dia termukan hati kita menjadi milik-Nya sepenuhnya? Akankah Dia berkata kepada kita seperti kepada Elia:”Ah, ya, hatinya menjadi milik-Ku sepenuhnya. Ya, ada komitmen yang cukup bagi_ku sehingga Aku dapat memakainya untuk melawan Ahab.Seperti Itulah pengabdian diri yang Aku cari."

Tidak Peduli dengan peran apapun yang kita mainkan dalam kehidupan, kita tetap penting untuk datang dan berdiri membela kebenaran. Bagian apa yang telah diberikan Allah pada kita? Apapun itu, Allah berkata:"Engkau sedang berdiri di hadapan- $\mathrm{Ku}$, dan aku ingin memakaimu. Aku ingin memakaimu sebagai juru bicara-Ku yang unik dalam hari-hari dan tahuntahun, pada saat ini dan nanti."

Nabi Elia, seorang yang berpenampilan kasar dan entah berasal dari mana, tiba-tiba muncul dalam lembaran sejaran, dan itu adalah suatu bukti yang jelas dari hidup seseorang yang sungguh-sungguh memberikan komitmennya pada Allah. Seorang Pria tidak dikenal yang berasal dari tempat terpencil, dipanggil untuk berdiri melawan kejahatan di masa yang tidak terkontrol dan penuh kekacauan.Kebutuhan seperti itu masih ada, dan Allah masih mencari.

Berbicara soal komitmen dalam diri pemimpin, maka John C. Maxwell memberikan arahannya kepada kita sebagai berikut [10]:

Jika kita ingin menjadi pemimpin yang efektif, kita harus memiliki Komitmen. Komitmen Sejati menginspirasikan serta menarik orang lain. Komitmen menunjukkan kepada orang lain bahwa kita punya keyakinan. Mereka akan percaya kepada kita hanya jika kita percaya kepada Tujuan kita sendiri. Seperti yang dikatakan Hukum Kepercayaan, Orang percaya kepada sang pemimpin dulu, baru visinya.

3 kesimpulan mengenai komitmen adalah:

(1) Komitmen Di mulai di Dalam Hati
Komitmen selalu mendahului prestasi. Jika kita ingin membuat perbedaan dalam kehidupan orang lain sebagai pemimpin, periksalah hati kita, apakah kita benar-benar berkomitmen

(2) Komitmen Diuji oleh Perbuatan Satu-satunya ukuran sejati dari komitmen adalah perbuatan.Bagaimanakah prestasi Kita dalam soal menindak-lanjuti komitmen-komitmen kita?

(3) Komitmen Membuka Pintu Menuju Prestasi Sebagai Pemimpin, Kita akan menghadapi banyak hambatan serta penentangan, dan akan ada saatnya ketika komitmen menjadi satu-satunya hal yang mendorong Kita untuk terus maju. Jadi Jika kita ingin mencapai sesuatu yang layak, Kita harus punya komitmen.

Dalam Soal komitmen, sesungguhnya ada empat jenis manusia yang dapat digolongkan ke dalamnya yaitu

(a) Golongan Pengecut yaitu orang yang tidak memiliki sasaran dan tidak punya komitmen.

(b) Golongan Peragu yaitu orang yang tidak tahu apakah mereka dapat mencapai sasarannya, maka mereka takut membuat komitmen.

(c) Golonan Penyerah yaitu orang yang mulai menuju suatu sasaran namun segera menyerah jika menemui hambatan.

(d) Golongan mati-matian yaitu orang yang menetapkan sasaran, berkomitmen untuk mencapainya, dan membayar harga untuk mencapainya.

Selanjutnya, setelah kita mengerti tentang komitmen, maka John C. Maxwell dalam bukunya yang sama melanjutkan pengarahannya yaitu bagi seorang pemimpin diperlukan untuk memiliki keberanian. Selama ini mungkin mudah terlihat dalam diri para pahlawan perang, namun keberanian juga tampak pada pemimpin besar dalam bisnis, pemerintahan, maupun gereja.Setiap kali kita melihat suatu kemajuan pesat dalam sebuah raganisasi, kita tahu bahwa pemimpinnya telah mengambil keputusan yang berani.Sebuah posisi kepemimpinan tidaklah memberikan keberanian kepada yang 
bersangkutan, namun keberanian dapat memberinya posisi dalam kepemimpinan.

4 hal tentang keberanian menurut John C. Maxwell yaitu:

(a) Keberanian Dimulai dengan Pergumulan Batin Setiap ujian yang kita hadapi sebagai pemimpin di mulai di dalam diri Kita, demikian juga dengan ujian Keberanian. Keberanian bukanlah berarti tidak adanya rasa takut, melainkan melakukan apa yang kita takut lakukan, memiliki kuasa untuk merelakan apa yang sudah kita kenal dan maju terus ke dalam wilayah baru.

(b) Keberanian artinya mengubah segalanya menjadi Benar, bukan sekedar meredakannya saja. Para pemimpin besar memiliki ketrampilan yang baik dalam membina hubungan dengan sesame, dan mereka dapat membuat orang lain berkompromi dan bekerjasama. Namun mereka juga pegang prinsip jika perlu.

Keberanian adalah menyangkut prinsip, bukannya persepsi.Jika kita tidak memiliki kemampuan untuk melihat kapan harus memegang teguh keyakinan kita dan melaksanakannya, kita takkan pernah dapat menjadi pemimpin yang efektif.

(c) Keberanian Dalam Diri Seorang Pemimpin Menginspirasikan Komitmen Dari Para Pengikutnya.

Keberanian yang diperlihatkan oleh siapapun akan menjadikan yang lainnya berani. Namun keberanian yang diperlihatkan seorang pemimpin akan memberikan inspirasi yang membuat orang lain ingin menjadi pengikutnya. Jim Melado menjelaskan "Kepemimpinan adalah ungkapan keberanian yang mendorong orang lain untuk melakukan hal yang benar."

(d) Kehidupan Kita Berkembang Menurut Keberanian Kita.

Rasa takut akan membatasi seorang pemimpin, namun keberanian membawa efek sebaliknya. Keberanian akan membuka pintu, dan itulah salah satu keuntungannya. Keberanian tidak saja memberi kita awal yang baik, melainkan juga memberikan masa depan yang lebih baik.

Yang menjadi ironinya adalah bahwa mereka yang tidak memiliki keberanian untuk mengambil resiko maupun mereka yang berani mengambil resiko sama - sama memiliki rasa takut dalam hidupnya. Satu-satunya perbedaan di antara keduanya adalah bahwa mereka yang tidak berani mengambil resiko hanyalah menguatirkan hal-hal yang sepele.Jadi jika kita harus mengatasi rasa takut dan keraguan kita, ya kita ambil resiko saja.

Dari Komitmen seorang pemimpin dibawa kepada hal keberanian, namun untuk bisa menuntaskan setiap persoalan, maka seorang pemimpin harus memiliki pengertian, sebab pengertian dapat digambarkan sebagai kemampuan untuk menemukan akar persoalan, dan ini tergantung pada intuisi serta nalar.Dan Pengertian adalah kualitas yang tak tergantikan bagi pemimpin manapun yang ingin memaksimalkan keefektifannya. Dan pengertian akan membantu mengerjakan beberapa hal penting sebagai berikut:

(1) Menemukan Akar Persoalan

Pengertian memungkinkan seorang pemimpin melihat sebagian gambarannya, melengkapinya secara intuitif, dan menemukan inti persoalannya.

(2) Meningkatkan Kemampuan Mengatasi Persoalan

Jika kita dapat melihat akar persoalan, kita dapat mengatasinya.Semakin dekat seorang pemimpin dengan hal ini, semakin kuat intuisinya dan kemampunya untuk melihat akar persoalan. Jika kita ingin memaksimalkan potensi pengertian kia, bekerjalan di bidang yang menjadi kekuatan kita.

(3) Mengevaluasi Pilihan-Pilihan yang Ada Demi Dampak Maksimal

Pengertian bukanlah hanya mengandalkan pada intuisi, atau hanya pada intelektual. Pengertian memungkinkan kita menggunakan firasat sekaligus nalar kita untuk menemukan pilihan terbaik bagi orang-orang kita serta organisasi kita.

(4) Melipatgandakan Kesempatan Kita 
Orang yang tidak memiliki pengertian jarang berada di tempat yang tepat di saat yang tepat dan pemimpin bisa menciptakan "keberuntungan" mereka sendiri berkat pengertian, kesediaan menggunakan pengalaman serta mengikuti naluri mereka.

Para pemimpin yang efektif selalu bangkit menghadapi tantangan.Itulah salah satu hal yang membedakan pemenang dengan perengek. Sementara retailer/pengecer yang lain mengeluh tentang persaingan maka pemimpin akan bangkit mengatasi berbagai persoalannya dengan kreativitas serta keuletan.

Apapun bidang yang ditekuni seorang pemimpin, ia pasti akan menghadapi banyak persoalan. Berbagai persoalan itu tak terhindarkan karena tiga alasan. Pertama, kita hidup di dunia yang semakin rumit serta semakin beragam. Kedua, kita berinterakasi dengan orang lain. Dan ketiga, kita tak mungkin mengendalikan semua situasi yang kita hadapi.

Para pemimpin yang memiliki kemampuan dalam memecahkan persoalan memperlihatkan lima kualitas sebagai berikut:

(a) Mereka Mengantisipasikan Berbagai persoalan Karena persoalan-persoalan itu tak terhindarkan, para pemimpin yang baik mengantisipasikannya. Siapapun yang mengharapkan jalan hidup ini mudah akan terus saja mengalami kesulitan. Jika Kita tetap memelihara sikap yang positif dan mengantisipsikan yang terburuk, kita akan memiliki posisi yang baik untuk mengatasi berbagai persoalan yang akan kita hadapi.

(b) Mereka Menerima Kebenaran

Orang dalam menanggapi persoalan bisa berupa : menolaknya, menerimanya dan menanggungnya, atau menerimanya dan berusaha menjadikan segalanya lebih baik. Para pemimpin harus selalu memilih respons yang terakhir.

(c) Mereka Melihat Gambaran Besarnya Para Pemimpin harus selalu melihat gambaran besarnya.Mereka tidak boleh dikuasai oleh emosi. Atau membiarkan diri begitu terpuruk dengan detil - detil sehingga melupakan hal yang terpenting.

(d) Mereka Tangani Satu Per Satu

Pemimpin yang paling sering mengalami masalah adalah mereka yang kewalahan akibat besarnya atau banyaknya persoalan mereka, alau coba-coba mengatasinya.Jika kita dihadapkan pada banyak persoalan, pastikanlah kita benar-benar menuntaskan yang sedang kita atasi sebelum pindah ke persoalan berikutnya.

(e) Mereka Pantang Menyerah

Pemimpin-pemimpin yang efektif memahami prinsip puncak ke puncak.Mereka mengambil keputusan-keputusan besar ketika sedang mengalami ayunan positif dalam kepemimpinnya, bukan ketika sedang mengalami masa sulit.

\section{PEMBAHASAN}

Seperti yang sudah Penulis sampaikan di atas bahwa tulisan ini untuk mengambil contoh dari seorang Nehemia, ketika Nehemia harus menghadapi perubahan baik lingkungan internal maupun eksternal dalam hidupnya mengiring Tuhan.

Melalui Nehemia ini, Penulis ingin mengajak kita semua melihat bahwa kehidupan pemimpin, kepribadian pemimpin bahkan hubungan pribadi pemimpin dengan Tuhan (khususnya hubungan dengan Pemimpin Agung kita yaitu Yesus Kristus dalam Matius 23:10[11]) dipengaruhi oleh sikap pemimpin itu sendiri di dalam mengantisipasi perubahan yang bisa terjadi sewaktuwaktu bahkan perubahan itu sendiri bisa bersifat sangat masif dan mengubah jalan hidup dari pemimpin dan seluruh unsur dalam organisasinya.

Dari Kajian Teoretis di atas, kita melihat bahwa Nehemia mengalami situasi dilemma pada saat awal kitab itu ditulis, sebab digambarkan dalam alkitab bahwa keadaan kota Yerusalem dengan tembok yang hancur dan pintu gerbang yang sudah tidak ada, yang diceritakan seorang yang bernama Hanani, membuat Nehemia terusik keberadaannya, emosi-nya maupun kerinduannya sehingga Nehemia berdoa kepada Tuhan dan 
mengharapkan Tuhan dapat membantunya untuk bisa berbuat sesuatu untuk Yerusalem.(Nehemia 1).

Maka seperti yang disampaikan oleh Spencer Johnson M.D. dalam bukunya "Who Moved My Cheese?" di atas, maka informasi yang disampaikan Hanani kepada Nehemia menjadi pemicu dalam perubahan yang drastis dalam kehidupan Nehemia. Perubahan itu termasuk di dalamnya adalah membawa kepada posisi Nehemia harus meninggalkan posisinya yang jika dilihat secara duniawi, sangat nyaman, dekat dengan Raja Arthasasta dan pasti memiliki fasilitas yang tidak akan dimiliki semua orang.

Tepat seperti yang dijabarkan dalam Kitab Nehemia Pasal 1, sejak saat itu, Nehemia menyadari bahwa akan ada Perubahan dan Nehemia mengantisipasi perubahan tersebut, lalu sejak saat itu dia memperhatikan perubahan yang ada dan Nehemia terus menyesuaikan diri dengan cepat, dan Nehemia siap untuk berubah.

Hal itu menjadi kenyataan dan tercatat dalam $\mathrm{Ne}$ hemia pasal 2, 4 bulan setelah laporan Hanani ke Nehemia dan ketika Raja Arthasasta melihat kegalauan hati Nehemia sehingga tidak biasa dalam menjalankan tugas rutinnya. Dan perenungan serta doa Nehemia menjadi kenyataan di mana Raja Arthasasta bertanya mengenai keinginan Nehemia dengan situasi yang diketahui tentang Yerusalem, dan bahkan permohonan Nehemia dikabulkan Raja untuk berangkat dan melakukan pemugaran atas Yerusalem.

BLAAR...! Perubahan terjadi... Nehemia harus siap untuk berangkat dan keluar dari rutinitas kehidupannya di Babel dan Nehemia harus mempersiapkan diri melakukan perjalanan kembali ke Yerusalem untuk menjalankan impiannya, visinya, misinya yang sudah dia gumulkan selama ini.

Situasi seperti inilah yang tertuang dalam bukunya Richard Templar yaitu "I Don't Want Any More Cheese" seperti yang Penulis paparkan dalam Kajian Teoretis di atas, sehingga kita dapat memahami kehidupan Nehemia saat dia mendapatkan persetujuan dari Raja Arthasasta. Bahkan tidak sampai hanya mendapat restu untuk bepergian, Raja digerakkan Tuhan untuk memperlengkapi segala keperluan yang dibutuhkan oleh Nehemia seperti surat kepada Bupati dan keperluan akan kayu, dan Nehemia memakai semua itu sesuai dengan rencana yang telah dia susun guna menyelesaikan misinya. Kita dapat temukan dalam Kitab Nehemia Pasal 2.[12]

Mungkin saja, dari sisi orang lain saat melihat $\mathrm{Ne}$ hemia mengambil keputusan yang radikal untuk meninggalkan Babel, akan dipandang sebagai kegagalan dan hal itu sah-sah saja, namun, bagi seorang pemimpin yang tidak mau terjebak kepada rutinitas kehidupan, dan mengejar mimpi yang sudah dia rindukan bahkan terlebih lagi kalau sang pemimpin ini sadar bahwa impiannya ini bukan sekedar impian tetapi hak istimewa dari Tuhan untuk dapat menyelesaikan misi yang ditugaskan Tuhan, maka dalam hal ini, si Pemimpin akan lebih semangat untuk membebaskan diri dari perangkap rutinitas hidup dan tidak menganggap semua fasilitas yang dia dapatkan sebagai kenikmatan lagi. (Richard Templar menggambarkannya berupa keju)

Keteguhan hati dari Nehemia inilah yang membuat Nehemia tidak ragu untuk berangkat dan meninggalkan Babel dan melangkah dengan keyakinan penuh untuk menyelesaikan misinya.

Yang menjadi pertanyaan pada posisi ini buat Kita semua, Adakah selaku pemimpin, kita siap melakukan seperti Nehemia, bersedia meninggalkan zona nyaman, mengantisipasi perubahan, siap menerima perubahan tersebut dan mengubah mimpi menjadi kenyataan melalui perencanaan yang matang?

Untuk menjawab pertanyaan di atas itulah yang dikatakan oleh Charles R. Swindoll bahwa Diperlukan kesadaran dan kesiapan kita untuk mau mengambil sikap menjadi perantara bagi Allah dan umatnya, bersedia berdiri di hadapan Allah dan terutama membuka diri selebar-lebarnya kepada cara Allah dalam memanggil, memerintah kita untuk pergi dan atau menentukan panggilan dalam hidup kita.

Lebih jauh kita mempelajari perjalanan Nehemia ini, tentunya dengan tuntunan penjelasan yang kita dapatkan dalam kajian teoretis di atas, maka kita semakin mendalami bagaimana kehidupan Nehemia yang sesungguhnya yaitu Nehemia memiliki komitmen yang penuh dalam menjalankan apa yang ada dalam hatinya, apa yang ada dalam impiannya, dan apa yang dicoba untuk diwujudkan dalam melakukan pemugaran tembok dan pintu gerbang Yerusalem. 
Komitmen inilah yang pada akhirnya membuat Yerusalem berhasil dipugar dan dikembalikan fungsinya. Dan semua ini karena Nehemia tunjukkan bahwa dia termasuk golongan yang mati-matian memperjuangkan apa yang dia yakini dan itu Nehemia buktikan melalui perbuatannya untuk melangkah keluar dari Babel, masuk ke Yerusalem dan melakukan perubahan di sana.

Tanpa keberanian yang tinggi, akan sangat sulit bagi Nehemia untuk menyelesaikan komitmen nya kepada Tuhan Allah. Hal itu ditunjukkan Nehemia dengan cara mendatangi para bupati yang daerahnya dilewati sehingga sampai ke Yerusalem, serta dapat membuat orang-orang sekitar membenci dan mencoba untuk menghambat semua langkah Nehemia.

Kalau kita lihat kembali apa yang disampaikan John C. Maxwell di bagian Kajian Teoretis, maka kita bisa merasakan keberanian Nehemia di mulai dari dalam bathinnya, dan hal itu terlihat dalam Kitab Nehemia Pasal 2: 11-20, yang menceritakan Nehemia melakukan survey lapangan di malam hari tanpa membawa rekannya, Nehemia menyelesaikan survey-nya, hanya berjalan sendiri dan tidak diketahui semua orang.

Hal ini membuahkan hasil yang baik dan berimbas kepada pengikutnya, serta memberikan semangat kepada para penduduk Yerusalem yang ada maupun orang-orang yang menemani Nehemia kembali ke Yerusalem.

Sampai di tahap ini, adakah kita sebagai pemimpin memiliki Komitmen dan Keberanian seperti yang dimiliki oleh Nehemia, Komitmen yang akan membawa kita berani mengejar impian yang sudah kita gumuli selama ini, dan keberanian yang akan membawa kita untuk dapat mengeksekusi tahapan-tahapan yang harus kita lewati dalam mengejar dan menuntaskan misi yang kita emban dari Tuhan.

Komitmen dan Keberanian yang ditunjukkan oleh Nehemia mendorongnya kepada tahapan pengertian dalam menyelesaikan semua impian yang Nehemia bawa sejak di Babel sampai di Yerusalem ini.

Nehemia menjadi mengerti bagaimana mengatasi semua hambatan dalam pembangunan, Mengerti bagaimana membungkam orang - orang atau pihak pihak yang mau menghambat proses pembangunan Tembok dan Pagar Yerusalem. Bagaimana mengantisipasi gangguan intimidasi yang dialami semua penduduk yang ikut dengan Nehemia, Bagaimana Nehemia mendapatkan pengertian untuk tetap bisa bekerja sambil menjaga diri dan kelompok dari kumpulankumpulan pencemooh, serta Bagaimana caranya Nehemia dapat melipat-gandakan kesempatan dalam menuntaskan misinya.

Lewat pengertian inilah, akhirnya kita juga dapat melihat bagaimana Nehemia dapat menjadi pemimpin yang efektif di dalam menyelesaikan setiap permasalahan-permasalahan yang harus dia lewati, karena seperti yang disampaikan oleh John C. Maxwell, pemimpin yang memiliki pengertian akan mampu menjadi pemimpin yang mampu menyelesaikan setiap persoalan yang harus dihadapinya, sebab Seperti Nehemia, dia dapat melihat gambaran besar yang ada dalam misinya yaitu agar Yerusalem kembali menjadi tempat yang cocok untuk bangsa Israel bisa menghampiri Tuhan dan beribadah kepadaNya.

Sebagai Pemimpin, adakah kita sudah memiliki pengertian yang benar dalam perjalanan kita menuntaskan tugas dan panggilan kita khususnya dalam mengejar impian yang sudah Tuhan tempatkan dalam hati dan iman kita yang hanya bisa kita pahami kalau kita memiliki waktu dan hubungan yang erat dengan Tuhan kita sebagai Sumber Kekuatan, Sumber Hikmat, Sumber Pengertian dan Sumber kehidupan sepenuhnya.

\section{KESIMPULAN}

Setiap Pemimpin hendaknya siap menghadapi perubahan baik perubahan itu bersifat biasa maupun bersifat radikal. Karena Perubahan tersebut sesungguhnya membawa kepada kebaikan bagi semua pihak termasuk di dalamnya adalah pemimpin, para pengikut maupun organisasi itu sendiri dalam hal ini gereja dan atau persekutuan.

Kemampuan mengantisipasi setiap perubahan termasuk yang radikal, akan memberikan pertumbuhan dan perkembangan yang baik menuju kepada pencapaian visi yang telah diangan-angankan.

Pemimpin harus memberi diri untuk selalu mengembangkan potensi diri yang ada sampai kepada titik optimumnya sehingga pemimpin dapat dengan kekoko- 
KERUSSO, VOLUME 3 NUMBER 1 MARET 2018

han diri yang terbaharukan dapat membawa seluruh organisme dalam organisasi menuju kepada pencapaian tujuan yang sudah ditetapkan.

Pemimpin harus selalu berhubungan dan berkomunikasi dengan Sumbernya yaitu Tuhan Yesus selaku Pemimpin Agung, agar pemimpin mendapatkan penyegaran secara rohani dan dapat mengeja-wantahkan kehendak Sang Pemimpin Agung, karena sesungguhsungguhnya dan sebenar-benarnya, gereja adalah milik Dia dan bukan milik Pemimpin.

\section{DAFTAR PUSTAKA}

[1] Maxwell, John C., Kepemimpinan, Jakarta: Yayasan Media Buana Indonesia, 1999.

[2] Idem.

[3] Alkitab Terjemahan Baru, Perjanjian Lama, Jakarta: LAI, 2017

[4] Idem.

[5] Swindoll, Charles R, Elia: Pria Heroik dan Rendah Hati, Jakarta: Nafiri Gabriel, 2001

[6] Hidayat Anwar, Penjelasan Lengkap Tentang Penelitian Kualitatf, https://www.statistikian.com/2012/10/penelitian-kualitatif.html, 2012

[7] Johnson Spencer M.D., Who Moved My Cheese?, Jakarta: PT. Elex Media Komputind, 2001

[8] Templar Richard, I Don't Want Any More Cheese, I Just Want Out Of The Trap , Jakarta: PT. Bhuana Ilmu Populer, 2005

[9] Swindoll, Charles R, Elia: Pria Heroik dan Rendah Hati, Jakarta: Nafiri Gabriel, 2001

[10] Maxwell, John C., The 21 Indispensable Qualities of A Leader, Batam: Interaksara, 2001

[11] Alkitab Terjemahan Baru, Perjanjian Baru, Jakarta: LAI, 2017

[12] Idem 